\title{
PERANAN SEKTOR PERTANIAN DALAM PEREKONOMIAN DAN PENYERAPAN TENAGA KERJA DI PROVINSI GORONTALO
}

\author{
Mohamad Arif Novriansyah Biki \\ Grace A. J. Rumagit \\ Charles R. Ngangi
}

\begin{abstract}
This research aimed to analyze the role of agricultural sector to analyze in the economy and labor Absorption in Gorontalo Province. This research was conducted over three months and started from June to August 2015 in Gorontalo Province. The data used in this research was secondary data which was obtained from Statistics Central Bureau of Gorontalo Province. The analysis used analysis of Location Quotient (LQ), Multiplier Short Run (MS), elasticity of labor, and Trend Linear by using the PDRB variable and numbers of labor force. The result of this research showed that the role of agricultural sector in the absorption of labor in Gorontalo Province is relatively stable in each year, and reviewed from PDRB terms the agricultural sector including the basis sector. Therefore, it needed continuing research to know factors which influence PDRB except the labor, which can increase PDRB of agricultural sector. Furthermore, the role of agricultural sector in absorption labor in Gorontalo Province is big enough and relatively stable in each year. Reviewed from PDRB aspect and labor aspect, agricultural sector was including the basic sector. Government of Gorontalo Province was expected to give more concern by increasing of investment and improving of human resources in agricultural sector.
\end{abstract}

Key words: Agricultural Sector, Location Quotient, Multiplier Share, Elasticity of Labor, Trend Linear.

\begin{abstract}
ABSTRAK
Penelitian ini bertujuan untuk menganalisis peranan sektor pertanian dalam perekonomian dan penyerapan tenaga kerja di Provinsi Gorontalo. Penelitian ini dilaksanakan selama tiga bulan mulai bulan juni hingga agustus 2015 di Provinsi Gorontalo. Data yang digunakan dalam penelitian ini adalah data sekunder yang diperoleh dari Badan Pusat Statistik Provinsi Gorontalo. Analis is ini menggunakan analisis Location Quotient (LQ), Multiplier Shortrun (MS), Elastisitas tenaga kerja, dan Trend Linier dengan menggunakan variable PDRB dan jumlah Tenaga kerja. Hasil penelitian ini menunjukkan bahwa peran sektor pertanian dalam penyerapan tenaga kerja di Provinsi Gorontalo relatif stabil setiap tahunnya, dan ditinjau dari PDRB sektor pertanian termasuk sektor basis. Untuk itu, perlu adanya penelitian lebih lanjut untuk mengetahui faktor-faktor yang mempengaruhi PDRB selain tenaga kerja, yang bisa meningkatkan PDRB sektor pertanian. Kemudian, peran sektor pertanian dalam perekonomian dan penyerapan tenaga kerja di Provinsi Gorontalo cukup besar dan relatif stabil setiap tahunnya. Dilihat dari aspek PDRB dan aspek tenaga kerja sektor pertanian merupakan sektor basis. Pemerintah Provinsi Gorontalo diharapkan memberikan perhatian yang lebih melalui peningkatan investasi dan peningkatan Sumber Daya manusia di sektor pertanian.
\end{abstract}

Kata Kunci : Sektor Pertanian, Location Quotient, Multiplier Share, Elastisitas Tenaga Kerja, Trend Linier. 


\section{PENDAHULUAN}

\section{Latar belakang}

Pembangunan pada hakikatnya adalah membuat sesuatu yang belum ada menjadi ada atau membuat sesuatu perubahan yaitu membuat sesuatu menjadi lebih baik atau meningkat. Pembangunan nasional yang berlandaskan pemerataan pembangunan dan hasil-hasilnya, pertumbuhan ekonomi yang cukup tinggi dan stabilitas nasional yang sehat dan dinamis merupakan isi dari trilogi pembangunan di mana di dalamnya juga terdapat unsur kesempatan kerja yang merupakan salah satu unsur dari pemerataan pembangunan dalam rangka mewujudkan kondisi perekonomian yang mantap dan dinamis.

Tren pertumbuhan perekonomian nasional selama tiga tahun terakhir terus mengalami perlambatan. Pada tahun 2014 pertumbuhan ekonomi Indonesia kembali melambat seiring dengan lesunya perekonomian global. Sempat mengalami pertumbuhan ekonomi yang cukup tinggi di tahun 2011 (6,17\%) 1, sejak tahun 2012 hingga 2014 pertumbuhan ekonomi Indonesia terus berkontraksi. Laju pertumbuhan ekonomi Indonesia tahun 2014 adalah sebesar 5,02 persen, melambat dibanding tahun 2013 yang sebesar 5,58 persen.

Pertumbuhan ekonomi nasional terjadi pada seluruh lapangan usaha. Informasi dan Komunikasi merupakan lapangan usaha yang mengalami pertumbuhan tertinggi sebesar 10,02 persen, diikuti oleh Jasa Perusahaan $(9,81 \%)$, dan Jasa Lainnya $(8,92 \%)$. Dari segi lapangan usaha, struktur perekonomian nasional didominasi oleh tiga lapangan usaha utama, yaitu: Industri Pengolahan (21,02 \%); Pertanian, Kehutanan, dan Perikanan (13,38 $\%)$; dan Perdagangan Besar-Eceran, Reparasi Mobil-Sepeda Motor (13,38 \%). Selain itu, di tahun 2014 sumber pertumbuhan ekonomi nasional tahun 2014 yang berasal dari Industri Pengolahan juga yang tertinggi, yaitu mencapai 1,01 persen.(BPS,2015)

Pembangunan sektor pertanian sebagai bagian integral dari pembangunan nasional semakin penting dan strategis. Pembangunan pertanian telah memberikan sumbangan besar dalam pembangunan nasional, baik sumbangan langsung dalam pembentukan PDB, penyerapan tenaga kerja, peningkatan pendapatan masyarakat, menyediakan sumber pangan dan bahan baku industri/biofuel, pemicu pertumbuhan ekonomi di pedesaan, perolehan devisa, maupun sumbangan tidak langsung melalui penciptaan kondisi kondusif bagi pelaksanaan pembangunan dan hubungan sinergis dengan sektor lain.

Dengan terciptanya lapangan pekerjaan ini diharapkan selain mampu menciptakan sumber-sumber pertumbuhan baru juga mampu mengurangi jumlah pengangguran dan kemiskinan yang selama ini melekat di wilayah pedesaan. Kemiskinan yang terjadi di pertanian disebabkan oleh rendahnya produktivitas di sektor tersebut dan yang terakhir ini erat kaitannya dengan distribusi lahan pertanian yang sangat timpang; walaupun Indonesia punya Undang-undang Agraris yang mengatur pembagian lahan secara adil. Di dalam literatur mengenai respons suplai di pertanian dikatakan bahwa petani yang positif responsnya terhadap kenaikan harga dan insentif - insentif produksi lainnya hanya jika petani mempunyai akses sepenuhnya terhadap faktor - faktor produksi seperti tanah, irigasi (air), modal, sumber daya manusia dan input - input krusial lainnya (Tambunan, 2006).

Sektor pertanian masih memegang peranan penting bagi perekonomian nasional. Setidaknya ada empat hal yang dapat dijadikan alasan. Pertama, Indonesia merupakan negara berkembang yang masih relatif tertinggal dalam penguasaan IPTEK mutakhir serta masih menghadapi kendala keterbatasan modal, jelas belum memiliki keunggulan komperatif pada sektor ekonomi yang berbasis IPTEK dan padat modal. Oleh karena itu pembangunan ekonomi Indonesia sudah selayaknya dititik beratkan pada pembangunan sektor-sektor ekonomi yang berbasis pada sumber daya alam, padat tenaga kerja dan berorientasi pada pasar domestik. Dalam hal ini, sektor pertanianlah yang paling memenuhi syarat. Provinsi Gorontalo merupakan salah satu Provinsi yang ada di pulau Sulawesi. Provinsi Gorontalo terdiri dari 5 Kabupaten dan 1 Kota yaitu, 
Kabupaten Boalemo, Kabupaten Pohuwato, Kabupaten Gorontalo, Kabupaten Bone Bolango dan Kota Gorontalo. Provinsi Gorontalo memiliki luas 12.435,00 km2. Jika dibandingkan dengan wilayah Indonesia, luas wilayah provinsi ini hanya sebesar 0,63 persen. Di kenal sebagai daerah yang memiliki potensi yang besar bagi pengembangan sektor pertanian, dimana beberapa komoditi yang dihasilkan adalah komoditi ekspor. Penurunan pertumbuhan Produk Domestik Regional Bruto (PDRB) dari 7,68 \% di tahun 2013 menjadi 7,29 \% Tahun 2014.

Dari sisi Sektoral nilai PDRB tertinggi dari Sektor Pertanian, Kehutanan, dan Perikanan sebesar 9,51 triliun Atas Dasar Harga Berlaku (ADHB). Dan 7,70 triliun Atas Dasar Harga Konstan (ADHK). Dimana PDRB ADHB tahun 2014 mencapai 25,20 triliun sedangkan ADHK mencapai 20,78 Triliun Rupiah.

Dari segi ketenagakerjaan, tercatat Tingkat Pengangguran Terbuka (TPT) Provinsi Gorontalo tahun 2014 adalah sebesar 4,18 persen, sedikit meningkat jika dibandingkan dengan tahun 2013 yang sebesar 4,15 persen. Dari total angkatan kerja, sebanyak 188.033 atau sekitar 35 persen tenaga kerja di Gorontalo bekerja di sektor Pertanian, Perkebunan, Kehutanan, Perburuan dan Perikanan.

Berdasarkan latar belakang diatas maka yang menjadi rumusan masalah dalam penelitian ini adalah bagaimana sektor pertanian dalam perekonomian dan penyerapan tenaga kerja di Provinsi Gorontalo.

\section{Perekonomian Suatu Wilayah}

Perekonomian wilayah secara umum dapat dianalisis pada dua aspek yaitu, analisis aspek sektoral dan analisis aspek regional. Perekonomian suatu wilayah dapat pula didefinisikan sebagai semua kegiatan yang dilaksanakan dalam suatu wilayah dimana kegiatan ekonomi tersebut terbagi dalam beberapa sektor dan sub-sub sektor serta dapat menghasilkan input dan output dalam rangka peningkatan kesejahteraan dan pemenuhan kebutuhan hidup.

\section{Teori Pertumbuhan Ekonomi Suatu Wiayah}

Pertumbuhan ekonomi merupakan laju pertumbuhan yang dibentuk dari berbagai macam sektor ekonomi yang secara pertum- buhan ekonomi adalah pertambahan pendapatan masyarakat secara keseluruhan yang terjadi di wilayah tersebut, yaitu kenaikan seluruh nilai tambah (value added) yang terjadi. Kemakmuran suatu wilayah selain ditentukan oleh besarnya nilai tambah yang tercipta di wilayah tersebut juga oleh seberapa besar terjadi transfer-payment, yaitu bagian pendapatan yang mengalir ke luar wilayah atau mendapat aliran dana dari luar wilayah (Tarigan, 2007).

\section{Pengertian Produk Domestik Regional Bruto (PDRB)}

Produk Domestik Regional Bruto (PDRB) adalah jumlah nilai tambah barang dan jasa yang dihasilkan dari seluruh kegiatan perekonomian di suatu daerah. Penghitungan PDRB menggunakan dua macam harga yaitu harga berlaku dan harga konstan. PDRB atas harga berlaku merupakan nilai tambah barang dan jasa yang dihitung menggunakan harga yang berlaku pada tahun bersangkutan, sementara PDRB atas dasar harga konstan dihitung dengan menggunakan harga pada tahun tertentu sebagai tahun dasar dan saat ini menggunakan tahun 2000 (BPS, 2014).

\section{Pengertian Sektor Pertanian}

Pengertian pertanian dalam arti sempit hanya mencakup pertanian sebagai budidaya penghasil tanaman pangan padahal kalau kita tinjau lebih jauh kegiatan pertanian dapat menghasilkan tanaman maupun hewan ternak demi pemenuhan kebutuhan hidup manusia.

\section{Konsep Tenaga Kerja}

Salah satu indikator yang terpenting dalam menilai perkembangan ekonomi adalah struktur tenaga kerja menurut sektor. Keseimbangan antara tenaga kerja di sektor-sektor produksi materiil (pertanian, pertambangan, industri dan bangunan) dengan sektor-sektor jasa sangat menentukan perkembangan ekonomi (Barthos,2004).

\section{Pengertian Tenaga Kerja}

Tenaga kerja adalah mereka yang melakukan pekerjaan untuk memperoleh pendapatan dan lamanya bekerja paling sedikit satu jam secara kontinyu dalam seminggu yang lalu (termasuk pekerja keluarga tanpa 
upah). Angkatan kerja adalah penduduk usia kerja yaitu 15 tahun keatas, yang bekerja/punya pekerjaan, sementara tidak bekerja dan yang sedang mencari pekerjaan (Prijono Tjiptoherijanto,1997).

\section{Perumusan Masalah}

Berdasarkan latar belakang dan masalah di atas, maka perumusan masalah penelitian ini adalah:

1. Bagaimana peran sektor pertanian dalam perekonomian di Provinsi Gorontalo ?

2. Bagaimana peran sektor pertanian dalam penyerapan tenaga kerja di Provinsi Gorontalo ?

\section{Tujuan Penelitian}

ini adalah :

Adapun yang menjadi tujuan penelitian

1. Menganalisis Peran sektor pertanian dalam perekonomian di Provinsi Gorontalo.

2. Menganalisis Peran sektor pertanian dalam penyerapan tenaga kerja di Provinsi Gorontalo.

\section{Manfaat Penelitian}

1. Bagi penulis, penelitian ini merupakan pelatihan intelektual (intellectual exercise) yang diharapkan dapat mempertajam daya pikir ilmiah serta meningkatkan kom-petensi keilmuan dalam disiplin ilmu yang digeluti.

2. Bagi masyarakat ilmiah, penelitian ini diharapkan dapat bermanfaat bagi ke-majuan dan pengembangan ilmu khu-susnya tentang pengetahuan pem-bangunan ekonomi pertanian di masa yang akan datang dan sebagai bahan referensi untuk penelitian lebih lanjut.

3. Bagi pemerintah, penelitian ini diharapkan dapat menjadi masukan dalam penentuan kebijakan pembangunan ekonomi khu-susnya yang berkaitan dengan faktor-faktor ekonomi makro terhadap pembangunan ekonomi pertanian.

\section{METODOLOGI PENELITIAN}

\section{Tempat dan Waktu Penelitian}

Tempat penelitian ini dilaksanakan di Dinas Pertanian Tanaman Pangan dan Holtikultura, dengan menggunakan data sekunder dimana pengumpulan data ini di peroleh dari
Badan Pusat Statistik Provinsi Gorontalo dan instansi terkait yang menyediakan data penelitian tersebut. Penelitian ini dilakukan sejak bulan JuniAgustus 2015.

\section{Jenis Dan Sumber Data}

Dalam upaya mempermudah pelaksanaan penelitian, terlebih dahulu diidentifikasi data yang terkandung dalam obyek penelitian sehingga variabel yang akan di analisis dapat dibedakan sebagai berikut :

1. Produk Domestik Regional Bruto (PDRB) Atas Dasar Harga Konstan (ADHK) tahun 2010 - 2014 Provinsi Gorontalo, yaitu keseluruhan nilai tambah bruto yang dihitung berdasarkan harga barang dan jasa pada tahun dasar.

2. Jumlah tenaga kerja menurut lapangan pekerjaan utama sektor pertanian di Provinsi Gorontalo tahun 2010 - 2014, data ini digunakan untuk analisis elastisitas penyerapan tenaga kerja.

3. Data sekunder lainnya yang berkaitan dengan penelitian ini.

\section{Konsep Pengukuran Variabel}

1. PDRB seluruh sektor di Provinsi Gorontalo tahun 2010 - 2014 Atas dasar Harga Konstan.

2. Produk Domestik Bruto (PDB) seluruh sektor tahun 2010 - 2014 Atas Dasar Harga Konstan.

3. PDRB Sektor Pertanian Provinsi Gorontalo tahun 2010 - 2014 Atas Dasar Harga Konstan.

4. PDB Sektor Pertanian tahun 2010 - 2014 Atas dasar Harga Konstan.

5. Jumlah Tenaga Kerja Seluruh Sektor Provinsi Gorontalo tahun 2010 - 2014

6. Jumlah Tenaga Kerja Seluruh Sektor Nasional tahun 2010 - 2014.

\section{Metode Analisis}

Untuk menganalisis peranan sektor pertanian dalam penyerapan tenaga kerja di Provinsi Gorontalo selama kurun waktu 20102014 dapat digunakan metode analisis data sebagai berikut : 


\section{Metode Location Quotient (LQ)}

Metode LQ membandingkan porsi lapangan kerja/nilai tambah untuk sector tertentu untuk lingkup wilayah yang lebih kecil dibandingkan dengan porsi lapangan kerja/nilai tambah untuk sektor yang sama untuk lingkup wilayah yang lebih besar.

$\mathrm{LQ}=\frac{x i / e}{X i / E}$

$\mathrm{Ii}=\mathrm{PDRB} /$ tenaga kerja sektor pertanian Provinsi Gorontalo

$\mathrm{e}=$ Total PDRB/tenaga kerja seluruh sektor di Provinsi Gorontalo

$\mathrm{Li}=\mathrm{PDRB} /$ tenaga kerja sektor pertanian nasional

$\mathrm{E}=$ Total PDRB/ tenaga kerja seluruh sektor nasional

Dari rumus diatas, apabila LQ $>1$ berarti porsi lapangan kerja atau nilai tambah sektor i di wilayah analisis terhadap total lapangan kerja atau nilai tambah wilayah adalah lebih besar dibandingkan dengan porsi lapangan kerja atau nilai tambah untuk sektor yang sama secara nasional. LQ $>1$ memberikan indikasi bahwa sektor tersebut adalah basis sedangkan apabila LQ $<1$ berarti sektor tersebut adalah non basis.

\section{Multiplier Basis Ekonomi}

$$
\mathrm{MS}=\frac{1}{1-\frac{N B}{N B+B}}
$$

Dimana :

MS : Multiplier Shortrun (multiplier jangka pendek)

NB : Pendapatan / tenaga kerja sektor non basis

B : Pendapatan/tenaga kerja sektor basis

\section{Elastisitas Tenaga kerja}

Untuk menganalisis peranan sektor pertanian terhadap penyerapan tenaga kerja di Provinsi Gorontalo, maka dapat dihitung laju pertumbuhan penyerapan tenaga kerja sektor pertanian dan pertumbuhan PDRB sektor pertanian di Provinsi Gorontalo dapat menggunakan rumus berikut ini (Arsyad 2004) :

$\mathbf{E}=\frac{\% \Delta \text { Tenaga kerja pada sektor pertanian }}{\% \Delta P D R B \text { sektor pertanian }}$

$\mathrm{E}$ : Elastisitas tenaga kerja

\section{Trend Linear}

Trend digunakan untuk memperkirakan kondisi di masa mendatang berdasarkan data pada masa lampau. Trend linear jika dinyatakan dalam bentuk persamaan matematika sebagaimana rumus persamaan garis linear. Dengan rumus ini dapat diperkirakan seberapa besar jumlah PDRB dan Jumlah tenaga kerja dimasa mendatang. Rumus persamaan trend linier sebagai berikut : Keterangan :

$$
\begin{aligned}
& \mathrm{x}=\text { Tahun } \\
& \mathrm{a}=\text { koefisiensi regresi } \\
& \mathrm{b}=\text { konstanta } \\
& \mathbf{Y}=\mathbf{a}+\mathbf{b} \mathbf{x}
\end{aligned}
$$

\section{HASIL DAN PEMBAHASAN}

\section{Deskripsi Wilayah Penelitian}

Provinsi Gorontalo ditinjau dari sudut geografis berada pada posisi Letak geografi berada di antara $121,23^{\prime}$ - 123,43 ' Bujur Timur dan $0,19^{\prime}-1,15^{\prime}$ Lintang Utara.

- Sebelah Utara berbatasan dengan Kabupaten Buol dan Toli Toli (Sulawesi Tengah dan Laut Sulawesi).

- Sebelah Barat berbatasan dengan Kabupaten Donggala (Sulawesi Tengah).

- Sebelah Timur berbatasan dengan Kabupaten Bolaang Mongondow (Sulawesi Utara).

Sebelah Selatan berbatasan dengan Teluk Tomini.

Provinsi Gorontalo mempunyai luas wilayah sebesar 12.435,44 $\mathrm{km} 2$ secara administrasi terbagi atas 1 kota dan 5 kabupaten, yaitu :

1. Kota Gorontalo

2. Kabupaten Gorontalo

3. Kabupaten Boalemo

4. Kabupaten Bone Bolango

5. Kabupaten Pohuwato

6. Kabupaten Gorontalo Utara 


\section{Keadaan Penduduk dan Ketenagakerjaan}

Penduduk Provinsi Gorontalo berdasarkan data tahun 2014 yang diperoleh dari lokasi penelitian sebesar 1.115.633 juta jiwa terbagi pada 5 Kabupaten dan 1 Kota, hal ini dapat dilihat pada Tabel 1.

Tabel 1. Jumlah dan Kepadatan Penduduk Provinsi Gorontalo

\begin{tabular}{lccc}
\hline \multicolumn{1}{c}{ Kabupaten / Kota } & $\begin{array}{c}\text { Penduduk } \\
\text { (jiwa) }\end{array}$ & $\begin{array}{c}\text { Luas Area } \\
\left(\mathrm{Km}^{2}\right)\end{array}$ & $\begin{array}{c}\text { Persentase } \\
\text { Luas Wilayah }\end{array}$ \\
\hline Kabupaten Boalemo & 145,580 & $1,736.61$ & 13.97 \\
Kabupaten Gorontalo & 368,149 & $2,143.48$ & 17.24 \\
Kabupaten Pohuwato & 143,338 & $4,455.60$ & 35.83 \\
Kabupaten Bone Bolango & 151,094 & $1,891.49$ & 15.21 \\
Kabupaten Gorontalo Utara & 109,502 & $2,141.86$ & 17.22 \\
Kota Gorontalo & 197,970 & 65.96 & 0.53 \\
\hline Jumlah & $\mathbf{1 , 1 1 5 , 6 3 3}$ & $\mathbf{1 2 , 4 3 5}$ & $\mathbf{1 0 0}$ \\
\hline
\end{tabular}

Sumber : BPS Gorontalo

Data penduduk tahun 2014 menunjukkan bahwa jumlah penduduk terbanyak berada di Kabupaten Gorontalo, yaitu 368.149 jiwa dengan luas wilayah 2.143 $\mathrm{Km}^{2}$. Sedangkan jumlah penduduk terkecil berada pada Kabupaten Gorontalo Utara dengan luas wilayah $2.141 \mathrm{Km}^{2}$.

Pada tahun 2014, penduduk usia kerja di Provinsi Gorontalo yang masuk angkatan Jika dilihat dari tingkat penyerapan tenaga kerja per sektor, terlihat bahwa pada tahun 2014 sektor pertanian menyerap sebagian besar jumlah tenaga kerja yaitu sebesar 188.033 jiwa atau sebesar $39 \%$, sektor Industri $9 \%$, sektor perdagangan $17 \%$, sektor jasa kemasyarakatan $18 \%$, sedangkan sektor lainnya sebesar $17 \%$.

kerja berjumlah 795.817 jiwa dan dari angkatan kerja yang ada tercatat 479.137 jiwa dari angkatan kerja yang ada. Sementara yang bukan angkatan kerja berjumlah 295.761 dan dari yang bukan angkatan kerja tercatat 84.448 jiwa yang bersekolah dan 174.438 jiwa yang mengurus rumah tangga.

Jika dilihat dari tingkat penyerapan tenaga kerja per sektor, terlihat bahwa pada tahun 2014 sektor pertanian menyerap sebagian besar jumlah tenaga kerja yaitu sebesar 188.033 jiwa atau sebesar $39 \%$, sektor Industri $9 \%$, sektor perdagangan $17 \%$, sektor jasa kemasyarakatan $18 \%$, sedangkan sektor lainnya sebesar $17 \%$.

\section{Gambar 1. Distribusi Tenaga Kerja menurut Lapangan Peker-jaan Utama Provinsi Gorontalo Tahun 2014}

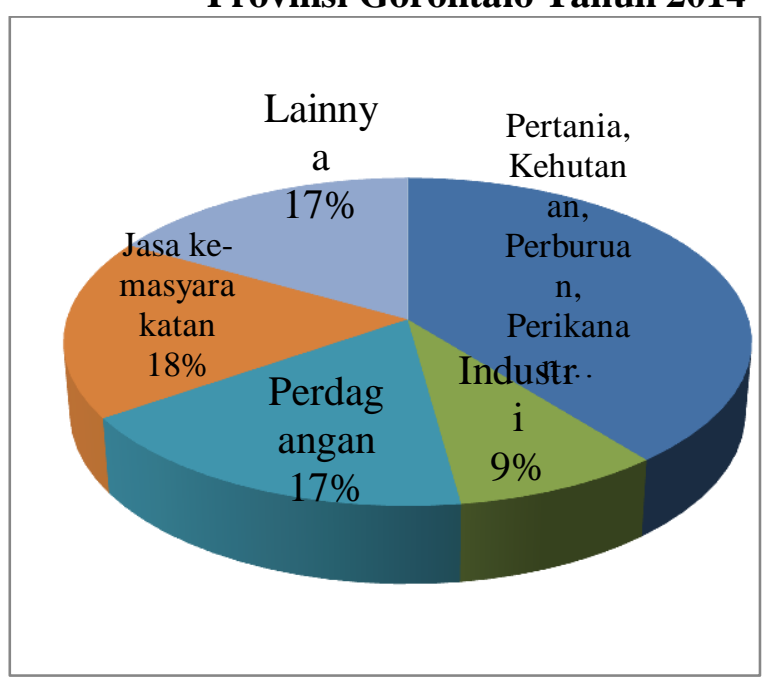

Sumber : BPS Gorontalo

\section{Pertumbuhan Ekonomi di Provinsi Gorontalo}

Pertumbuhan ekonomi adalah proses perubahan kondisi perekonomian suatu daerah secara berkesinambungan menuju keadaan yang lebih baik dari waktu ke waktu. Pertumbuhan ekonomi dapat diartikan juga sebagai proses kenaikan kapasitas produksi suatu perekonomian yang diwujudkan dalam bentuk kenaikan pendapatan nasional. Adanya pertumbuhan ekonomi merupakan indikasi keberhasilan pembangunan ekonomi. Alat untuk mengukur laju pertumbuhan ekonomi adalah dengan melihat Produk Domestik Regional Bruto (PDRB) sebagai indikator ekonomi serta dapat menggambarkan kondisi perekonomian di suatu daerah termasuk Provinsi Gorontalo.

Laju pertumbuhan ekonomi berdasarkan lapangan usaha di Provinsi Gorontalo, dapat dilihat pada Tabel 2.

Selang tahun $2010 \quad-\quad 2014$ Pertumbuhan ekonomi Provinsi Gorontalo atas dasar harga konstan berada pada kisaran $7,29 \%$ hingga $7,91 \%$ dengan rata - rata pertumbuhan $7,6 \%$ per tahun. Pada sektor pertanian pertumbuhan tertinggi terjadi pada tahun 2010 yaitu sebesar 38,63\%, sedangkan terendah pada tahun 2014. Rata - rata pertumbuhan ekonomi khususnya sektor pertanian adalah $7,7 \%$ per tahun. Sektor lain 
yang memiliki pertumbuhan yang cukup tinggi di Gorontalo adalah sektor bangunan, sektor perdagangan, hotel dan restoran, sektor keuangan, real estate, dan jasa perusahaan dengan rata-rata pertumbuhan masing masing sektor 11,8\% (Bangunan), 12,1\% (perdagangan, hotel dan restoran), $15 \%$ (keuangan, real estate, dan jasa perusahaan)

Tabel2 Laju Pertumbuhan Ekonomi Menurut Lapangan Usaha di Provinsi Gorontalo Tahun $2010-2014$

\begin{tabular}{llrrrrr}
\hline & & \multicolumn{5}{c}{ Tahun } \\
\cline { 3 - 7 } No Lapangan Usaha & & 2010 & 2011 & 2012 & 2013 & 2014 \\
\cline { 3 - 7 } & & & & & \\
\hline 1 & Pertanian & 1.63 & 37.92 & 37.60 & 37.34 & 37.04 \\
2 & Pertambangan & 1.52 & 1.48 & 1.41 & 1.36 \\
3 & Industri Pengolahan & 4.09 & 4.09 & 4.10 & 4.11 & 4.06 \\
4 & Listrik, Gas dan Air Bersih & 0.12 & 0.12 & 0.12 & 0.12 & 0.12 \\
5 & Bangunan & 11.73 & 11.92 & 11.88 & 11.83 & 11.89 \\
6 & Perdagangan, Hotel dan Restoran & 11.68 & 11.90 & 12.17 & 12.44 & 12.51 \\
7 & Pengangkutan dan Komunikasi & 8.30 & 8.39 & 8.44 & 8.52 & 8.64 \\
8 & Keuangan, Real Estate, dan jasa Perusahaan & 15.08 & 15.24 & 15.10 & 14.88 & 14.78 \\
9 & Jasa - Jasa & 8.84 & 8.89 & 9.10 & 9.35 & 9.60 \\
\hline \multicolumn{2}{c}{ Pertumbuhan Ekonomi } & 7.56 & 7,73 & 7,91 & 7.78 & 7,29 \\
\hline
\end{tabular}

Sumber : BPS Gorontalo 2015

\section{Keadaan Sektor Pertanian}

Sektor Pertanian merupakan salah satu lapangan pekerjaan utama masyarakat di Provinsi Gorontalo, sesuai dengan data yang diperoleh dari Badan Pusat Statistik Provinsi Gorontalo tercatat PDRB sektor pertanian sebagai berikut :

\begin{tabular}{|c|c|c|c|}
\hline & $\begin{array}{l}\text { Bruto Sektor Pertanian Atas Dasar } \\
\text { Konstan Provinsi Gorontalo Tahun }\end{array}$ & $\begin{array}{l}\text { Harga } \\
2010-2014\end{array}$ & \\
\hline Tahun & $\begin{array}{l}\text { PDRB Sektor Pertanian Atas Dasar } \\
\text { Harga Konstan (Miliar Rupiah) }\end{array}$ & $\begin{array}{c}\text { Pertumbuhan } \\
\qquad \% \mid\end{array}$ & $\begin{array}{c}\text { Pertumbuhan } \\
\text { rata- rata }\end{array}$ \\
\hline 2010 & $5.977 .734,8$ & 6,6 & - \\
\hline 2011 & 6.321.225,6 & 7,0 & - \\
\hline 2012 & $6.763 .846,4$ & 7,5 & 7,5 \\
\hline 2013 & $7.232 .594,6$ & 8,0 & - \\
\hline 2014 & $7.698 .324,0$ & 8,5 & - \\
\hline
\end{tabular}

Sumber: BPS Gorontalo 2015

Produk Domestik Regional Bruto (PDRB) merupakan salah satu indikator pertumbuhan ekonomi yang dipengaruhi antara lain oleh infrastruktur ekonomi. PDRB yaitu jumlah nilai tambah bruto yang dihasilkan dari seluruh sektor perekonomian suatu wilayah dalam waktu tertentu. Sektor pertanian adalah salah satu sektor yang memberikan kontribusi terbesar terhadap PDRB Provinsi Gorontalo. Pertumbuhan sektor pertanian dalam beberapa tahun terakhir (Gambar 3).

\section{Gambar 2. Grafik Pertumbuhan Sektor Pertanian Provinsi Gorontalo Tahun 2010 - 2014}

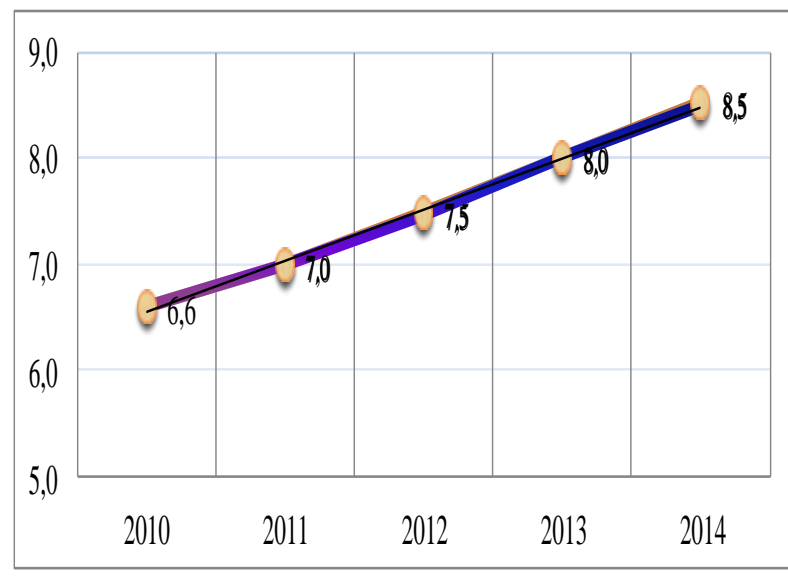

Sumber : BPS Gorontalo, diolah dari lampiran 2

Gambar 2 menunjukkan bahwa setiap tahun sektor pertanian mengalami kenaikan. Pada tahun 2011 naik sebesar 0,4 \% dari 6,6\% di tahun 2010. Kemudian dari tahun 2011 hingga 2014 naik sebesar $0,5 \%$ setiap tahun.

\section{Kontribusi PDRB Sektor Pertanian}

Pada Tabel 4 menunjukkan kontribusi PDRB sektor pertanian terhadap pem-bentukan PDB.

Tabel4. Kontribusi PDB Sektor Pettanian Terhadap Pembentukan PDB

\begin{tabular}{rrrr}
\hline Tahun & $\begin{array}{c}\text { PDB Sektor Pertanian } \\
\text { (Milyar Rupiah) }\end{array}$ & $\begin{array}{c}\text { TotalPDB } \\
\text { (Milyar Rupiah) }\end{array}$ & Kontribusi(\%) \\
\hline 2010 & $304.777,1$ & $2.314 .458,8$ & 13,2 \\
2011 & $315.036,8$ & $2.464 .566,1$ & 12,8 \\
2012 & $328.279,7$ & $2.618 .932,0$ & 12,5 \\
2013 & $339.560,8$ & $2.769 .053,0$ & 12,3 \\
2014 & $350.722,2$ & $2.909 .181,5$ & 12,1 \\
\hline
\end{tabular}

Sumber: Diolah dari lampiran 3 
Menunjukkan bahwa kontribusi PDB sektor pertanian yang cenderung menurun setiap tahunnya. Selama kurun waktu 20102014 sektor pertanian menyumbang sebesar $12,6 \%$ dari total PDB.

Tabel 5. Kontribusi PDRB Sektor Pertanian Provinsi Gorontalo

Terhadap Pembentukan PDRB Sektor Pertanian

\begin{tabular}{rrrc}
\hline Tahun & $\begin{array}{c}\text { PDRB Sektor Pertanian } \\
\text { (Milyar Rupiah) }\end{array}$ & $\begin{array}{c}\text { Total PDRB } \\
\text { (Milyar Rupiah) }\end{array}$ & Kontribusi (\%) \\
\hline 2010 & $5,977,734.80$ & $15,475,736.81$ & 38.6 \\
2011 & $6,321,225.63$ & $16,669,089.60$ & 37.9 \\
2012 & $6,763,846.43$ & $17,987,074.87$ & 37.6 \\
2013 & $7,232,594.63$ & $19,369,153.21$ & 37.3 \\
2014 & $7,698,324.02$ & $20,781,308.25$ & 37.0 \\
\hline
\end{tabular}

Sumber: Diolah dari lampiran 3

Di tingkat Provinsi, sektor pertanian merupakan salah satu sektor yang memberikan kontribusi terbesar dalam pembentukan PDRB. Kontribusi PDRB sektor pertanian cenderung menurun selama kurun waktu 2010 - 2014 menyumbang kontribusi sebesar $37,7 \%$ dari total PDRB Provinsi Gorontalo.

\section{Kontribusi Tenaga Kerja Sektor Pertanian}

Tabel 6 menunjukkan bahwa kontribusi jumlah tenaga kerja di sektor pertanian nasional mengalami penurunan jumlah tenaga kerja setiap tahunnya dari tahun 2010 ke tahun 2011 sebesar $3,1 \%$ dari tahun 2010 yang berjumlah 43,243,111 jiwa menjadi 39,088,271 jiwa pada tahun 2011.

Tabel 6. Kontribusi Jumlah Tenaga Kerja Sektor Pertanian

Terhadap Jumlah Tenaga Kerja Nasional

\begin{tabular}{|c|c|c|c|}
\hline Tahun & $\begin{array}{l}\text { Jumlah Tenaga Kerja } \\
\text { Sektor Pertanian(jiwa) }\end{array}$ & $\begin{array}{l}\text { Jumlah Tenaga Kerja } \\
\text { Nasional (jiwa) }\end{array}$ & Kontribusi $(\%)$ \\
\hline 2009 & $43,243,111$ & $109,589,715$ & 39.5 \\
\hline 2010 & $39,088,271$ & $107,416,309$ & 36.4 \\
\hline 2011 & $39,590,054$ & $112,504,868$ & 35.2 \\
\hline 2012 & $39,220,261$ & $112,761,072$ & 34.8 \\
\hline 2013 & $38,973,033$ & $114,628,026$ & 34.0 \\
\hline
\end{tabular}

Sumber: Diolah dari lampiran 4

Pada Tabel 7 kontribusi tenaga kerja sektor pertanian terhadap jumlah tenaga kerja di Provinsi Gorontalo.
Sepanjang tahun 2010 hingga 2014 tenaga kerja sektor pertanian di Provinsi Gorontalo kurang stabil. Dimana terjadi penurunan di tahun 2010 ke tahun 2011 dari 176,974 jiwa menjadi 165,133 jiwa di tahun 2011. Kemudian naik pada tahun 2013 ke tahun 2014 dari 169,416 jiwa menjadi 188,033 jiwa.

Tabel 7. Kontribusi Jumlah Tenaga Kerja Sektor Pertanian Terhadap Jumlah Tenaga Kerja ProvinsiGorontalo

\begin{tabular}{crrr}
\hline Tahun & $\begin{array}{c}\text { Jumlah Tenaga Kerja } \\
\text { Sektor Pertanian (jiwa) }\end{array}$ & $\begin{array}{c}\text { Total Tenaga Kerja } \\
\text { (jiwa) }\end{array}$ & $\begin{array}{c}\text { Kontribusi } \\
(\%)\end{array}$ \\
\hline 2010 & 176.974 & 432.926 & 40,88 \\
2011 & 165.133 & 450.767 & 36,63 \\
2012 & 173.235 & 458.409 & 37,79 \\
2013 & 169.416 & 458.930 & 36,92 \\
2014 & 188.033 & 479.137 & 39,24 \\
\hline
\end{tabular}

Sumber: Diolah dari lampiran 5

\section{Analisis Sektor Pertanian}

\section{Location Quotient PDRB Sektor Pertanian Provinsi Gorontalo}

Penggolongan sektor pada suatu wilayah ke dalam sektor basis dan non basis dapat dilakukan dengan menggunakan analisis Location Quotient (LQ), yang bertujuan untuk mengetahui besarnya peranan sektor tersebut secara nasional.

Nilai Location Quotient (LQ) PDRB sektor pertanian Provinsi Gorontalo dapat dilihat pada Tabel 8 berikut ini.

Tabel 8. Nilai Location Quotient (LQ) PDRB Sektor Pertanian Provinsi Gorontalo Tahun 2010 - 2014

\begin{tabular}{|c|c|c|c|c|c|}
\hline Tahun & $\begin{array}{c}\text { PDRB Sektor } \\
\text { Pertanian } \\
\text { Gorontalo }\end{array}$ & $\begin{array}{c}\text { Total PDRB } \\
\text { Gorontalo }\end{array}$ & $\begin{array}{c}\text { PDB Sektor } \\
\text { Pertanian }\end{array}$ & TotalPDB & $\begin{array}{c}\text { LQ } \\
\text { Sektor } \\
\text { Pertanian }\end{array}$ \\
\hline 2010 & $5,977,734.8$ & $15,475,736.8$ & $304,777.1$ & $2,314,458.8$ & 2.9 \\
\hline 2011 & $6,321,225.6$ & $16,669,089.6$ & $315,036.8$ & $2,464,566.1$ & 3.0 \\
\hline 2012 & $6,763,846.4$ & $17,987,074.9$ & $328,279.7$ & $2,618,932.0$ & 3.0 \\
\hline 2013 & $7,232,594.6$ & $19,369,153.2$ & $339,560.8$ & $2,769,053.0$ & 3.0 \\
\hline 2014 & $7,698,324.0$ & $20,781,308.3$ & $350,722.2$ & $2,909,181.5$ & 3.1 \\
\hline
\end{tabular}

Sumber Diolah dari Lampiran $2 \& 3$ 
Dari hasil perhitungan Tabel 8 menunjukkan bahwa nilai Location Quotient PDRB sektor pertanian berada diatas angka 1 atau LQ > 1. Hal ini menunjukkan bahwa dari segi pen-dapatan, sektor pertanian merupakan sektor basis yang lebih tinggi perbandingannya dengan sektor lain.

\section{Location Quotient Tenaga Kerja Sektor Pertanian Provinsi Gorontalo}

Tabel 9. Nilai Location Quotient (LQ) Tenaga Kerja Sektor Pertanian Provinsi Gorontalo Tahun 2010 - 2014

\begin{tabular}{|c|c|c|c|c|c|}
\hline Tahun & $\begin{array}{l}\text { Tenaga Kerja } \\
\text { Sektor Pertanian } \\
\text { Gorontalo } \\
\text { (Jiwa) }\end{array}$ & $\begin{array}{c}\text { Total Tenaga } \\
\text { Kerja di } \\
\text { Gorontalo } \\
\text { (Jiwa) }\end{array}$ & $\begin{array}{c}\text { Tenaga Kerja } \\
\text { Sektor } \\
\text { Pertanian } \\
\text { Nasional } \\
\text { (Jiwa) }\end{array}$ & $\begin{array}{c}\text { Total Tenaga } \\
\text { Kerja } \\
\text { Nasional } \\
\text { (Jiwa) }\end{array}$ & $\begin{array}{c}\text { LQ } \\
\text { Tenaga } \\
\text { Kerja }\end{array}$ \\
\hline 2010 & 176,974 & 432,926 & $43,243,111$ & $109,589,715$ & 1.04 \\
\hline 2011 & 165,133 & 450,767 & $39,088,271$ & $107,416,309$ & 1.01 \\
\hline 2012 & 173,235 & 458,409 & $39,590,054$ & $112,504,868$ & 1.07 \\
\hline 2013 & 169,416 & 458,930 & $39,220,261$ & $112,761,072$ & 1.06 \\
\hline 2014 & 188,033 & 479,137 & $38,973,033$ & $114,628,026$ & 1.15 \\
\hline
\end{tabular}

Sumber Diolah dari lampiran 4 \& 5

Pada Tabel 9 perhitungan menunjukkan bahwa nilai LQ tenaga kerja sektor pertanian Provinsi Gorontalo berada pada angka 1 atau LQ > 1. Hal ini menunjukkan bahwa dari segi penyerapan tenaga kerja sektor pertanian Provinsi Gorontalo merupakan sektor basis yang lebih tinggi perbandingannya.

\section{Analisis Multiplier Basis Ekonomi}

Analisis Multiplier PDRB Sektor Pertanian Provinsi Gorontalo.

Tabel 10 Analisis Multiplier PDRB Sektor Pertanian Provinsi Gorontalo Tahun 2010 - 2014

\begin{tabular}{ccrc}
\hline Tahun & $\begin{array}{c}\text { PDRB Sektor } \\
\text { Basis (Miliar } \\
\text { Rupiah) }\end{array}$ & $\begin{array}{c}\text { Total PDRB } \\
\text { sektor Non } \\
\text { Basis (jiwa) }\end{array}$ & $\begin{array}{c}\text { Nilai Multiplier } \\
\text { Pendapatan } \\
\text { (MS) }\end{array}$ \\
\hline 2010 & $5,977,735$ & $9,498,002$ & 2.59 \\
2011 & $6,321,226$ & $10,347,864$ & 2.64 \\
2012 & $6,763,846$ & $11,223,228$ & 2.66 \\
2013 & $7,232,595$ & $12,136,559$ & 2.68 \\
2014 & $7,698,324$ & $13,082,984$ & 2.70 \\
\hline
\end{tabular}

Sumber Diolah dari lampiran 2
Hasil analisis menunjukkan bahwa pada tahun 2010 nilai Multiplier Shortrun (MS) sama dengan 2,59. Nilai ini dapat di interpretasikan jika kegiatan ekonomi sektor pertanian meningkat Rp. 1.000.000, maka akan membawa perubahan sebesar Rp.2.590.000. Angka 2,64 pada tahun 2011 menunjukkan terjadinya kenaikan Rp.2.640.000 jika sektor pertanian meningkat Rp. 1.000.000. Nilai MS pada tahun 2012 sebesar 2,66 yang berarti kegiatan sektor pertanian meningkat Rp. 1.000 .000 menyebabkan kenaikan sebesar Rp 2.660.000 Pada tahun 2013 menunjukkan adanya kenaikan sebesar 2,68, angka tersebut menggambarkan terjadinya kenaikan sebanyak Rp 2.680.000. Dan pada tahun 2014 sebesar 2,70 memberikan gambaran terjadinya kenaikan sebanyak Rp. 2.700.000 pada perekonomian Provinsi Gorontalo.

\section{Analisis Multiplier Tenaga Kerja Sektor Pertanian Provinsi Gorontalo}

Hasil analisis menunjukkan bahwa pada tahun 2010 nilai Multiplier Shortrun (MS) sama dengan 2,45. Nilai ini dapat di interpretasikan jika kegiatan ekonomi sektor pertanian meningkat Rp. 1.000, maka tenaga kerja yang bekerja pada sektor pertanian akan meningkat sebesar 2.450 jiwa.

Tabel 11. Analisis Multiplier Tenaga Kerja Sektor Pertanian Provinsi Gorontalo Tahun 2010 - 2014

\begin{tabular}{ccrc} 
Tahun & $\begin{array}{c}\text { Jumlah Tenaga } \\
\text { Kerja Sektor Basis } \\
\text { (jiwa) }\end{array}$ & $\begin{array}{c}\text { Jumlah Tenaga } \\
\text { Kerja Non Basis } \\
\text { (jiwa) }\end{array}$ & $\begin{array}{c}\text { Nilai Multiplier } \\
\text { Tenaga Kerja } \\
\text { (MS) }\end{array}$ \\
\hline 2010 & 176,974 & 255,952 & 2.45 \\
2011 & 165,133 & 285,634 & 2.73 \\
2012 & 173,235 & 285,174 & 2.65 \\
2013 & 169,416 & 289,514 & 2.71 \\
2014 & 188,033 & 291,104 & 2.55 \\
\hline
\end{tabular}

Sumber : Diolah dari lampiran 4

Angka 2,73 pada tahun 2011 menunjukkan terjadinya kenaikan tenaga kerja sebanyak 2.700 jiwa jika sektor 
pertanian meningkat Rp. 1.000. Nilai MS pada tahun 2012 mengalami penurunan, hal itu dapat dilihat dari nilai MS sebesar 2,65 jiwa yang berarti kegiatan sektor pertanian meningkat Rp. 1000 menyebabkan kenaikan sebesar 2.650 jiwa. penurunan MS di tahun ini disebabkan oleh penurunan jumlah tenaga kerja non basis. Pada tahun 2013 menunjukkan adanya kenaikan sebesar 2,71, angka tersebut menggambarkan terjadinya kenaikan tenaga kerja sebanyak 2.710. Dan pada tahun 2014 sebesar 2,55 memberikan gambaran terjadinya kenaikan tenaga kerja sebanyak 2.550 jiwa jika kegiatan sektor pertanian meningkat Rp. 1000. Penurunan MS di tahun ini apabila dibandingkan dengan tahun sebelumnya diakibatkan oleh jumlah peningkatan tenaga kerja non basis tahun 2014 tidak sebesar peningkatan yang terjadi di tahun 2013.

\section{Elastisitas Tenaga Kerja Sektor Pertanian Provinsi Gorontalo}

Tabel 12 menunjukkan elastisitas tenaga kerja sektor pertanian Provinsi Gorontalo.

Tabel 12. Elastistas Tenaga Kerja Sektor Pertanian Provinsi Gorontalo

\begin{tabular}{crrr} 
Tahun & $\begin{array}{c}\text { Jumlah Tenaga Kerja } \\
\text { Sektor Pertanian } \\
\text { (jiwa) }\end{array}$ & $\begin{array}{c}\text { PDRB Sektor } \\
\text { Pertanian } \\
\text { (jiwa) }\end{array}$ & $\begin{array}{c}\text { Elastisitas } \\
\text { Penyerapan } \\
\text { Tenaga Kerja }\end{array}$ \\
\hline 2010 & 176.974 & 5.977 .735 & - \\
2011 & 165.133 & 6.321 .226 & $-1,16$ \\
2012 & 173.235 & 6.763 .846 & 0,70 \\
2013 & 169.416 & 7.232 .595 & $-0,32$ \\
2014 & 188.033 & 7.698 .324 & 1,71 \\
\hline
\end{tabular}

Sumber: Diolah dari lampiran $2 \& 4$

Pada tahun 2011 elastisitas tenaga kerja sektor pertanian Gorontalo adalah -1,16. Ini menunjukkan terjadinya penurunan jumlah tenaga kerja sebesar 1,16\% jika PDRB Gorontalo naik sebesar $1 \%$. Pada tahun 2012 elastisitas tenaga kerja mengalami kenaikan sebesar 0,70 nilai tersebut menunjukkan bahwa terjadi kenaikan sebesar
0,7\%. Kemudian pada tahun 2013 elastisitas tenaga kerja Gorontalo mengalami penurunan sebesar 0,32 \% dan pada tahun 2014 naik menjadi $1,71 \%$.

\section{Trend Linier}

Analisis trend linier dapat memperkirakan seberapa besar jumlah PDRB $\mathrm{a}=33.993 .726,5 / 5=6.798 .745,1$ $\mathrm{a}=33.993 .726,5 / 5=6.798 .745,1$ $\mathrm{b}=4.352 .547,4 / 10=435.254,74$

Berdasarkan nilai a dan $b$ diatas maka diperoleh persamaan trend sebagai berikut :

$Y=6.798 .745,1+435.254,74(X)$

Dimana dari persamaan ini menunjukkan bahwa rata rata PDRB selang waktu 5 tahun $(2010$ - 2014) adalah sebesar Rp. 6.798.745.100.000 dan diproyeksikan setiap tahun berikutnya akan mengalami peningkatan sebesar Rp. 435.254.740.000.

dan jumlah tenaga kerja dimasa yang akan datang berdasarkan data pada masa lampau.

$\mathrm{a}=\sum \mathrm{xy} \div \sum \mathrm{x}^{2}$

$$
\mathbf{Y}=\mathbf{a}+\mathbf{b x}
$$

$\mathbf{b}=\sum \mathbf{y} \div \mathbf{n}, \mathbf{n}$ adalah jumlah data

Tabel13 Persamaan Trend Limier

\begin{tabular}{clrrc}
\hline tahun & $y$ & $x$ & $x^{2}$ & $x y$ \\
\hline 2010 & $5,977,734.8$ & -2 & 4 & $(11,955,469.6)$ \\
2011 & $6,321,225.6$ & -1 & 1 & $(6,321,225.6)$ \\
2012 & $6,763,846.4$ & 0 & 0 & - \\
2013 & $7,232,594.6$ & 1 & 1 & $7,232,594.6$ \\
2014 & $7,698,324.0$ & 2 & 4 & $15,396,0448.0$ \\
\hline$\Sigma$ & $33,993,725.5$ & 0 & 10 & $4,352,547.4$ \\
\hline
\end{tabular}

Sumber: Diolah Darilampiran2

$y=a+b x$

$\mathrm{a}=33.993 .726,5 / 5=6.798 .745,1$

$\mathrm{b}=4.352 .547,4 / 10=435.254,74$

Berdasarkan nilai a dan $\mathrm{b}$ diatas maka diperoleh persamaan trend sebagai berikut : 


\section{$Y=6.798 .745,1+435.254,74(X)$}

Dimana dari persamaan ini menunjukkan bahwa rata rata PDRB selang waktu 5 tahun $(2010$ - 2014) adalah sebesar Rp. 6.798.745.100.000 dan diproyeksikan setiap tahun berikutnya akan mengalami peningkatan sebesar Rp. 435.254.740.000.

Tabel14 Perkiraan PDRB Sektor Pertanian Provinsi Gorontalo

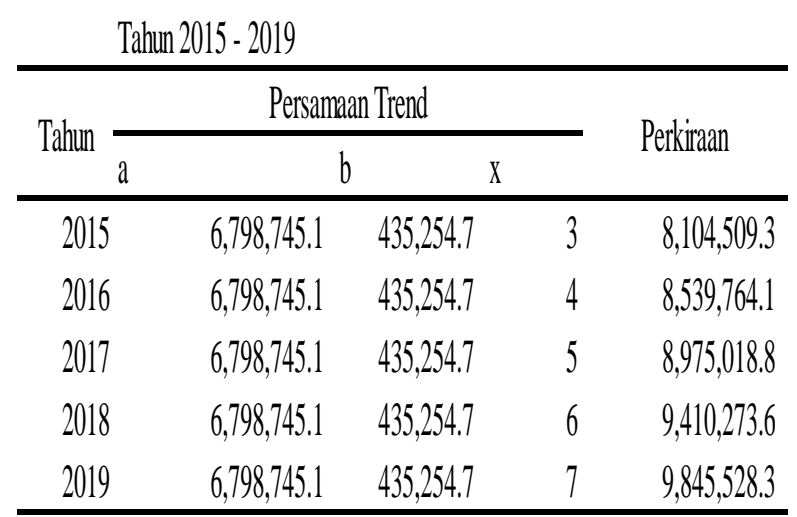

Sumber: Diolah Dari lampiran 2

Berdasarkan Tabel 14 pada tahun 2015 diproyeksikan PDRB akan meningkat sebesar Rp.8.104.509.300.000 atau terjadi peningkatan sebanyak $5 \%$ jika dibandingkan dengan PDRB tahun pengamatan terakhir (2014).

Berdasarkan Tabel 14 juga dapat dilihat Tahun 2016 diproyeksikan PDRB akan meningkat sebesar Rp.8.539.764.100.000 atau terjadi peningkatan sebanyak $11 \%$ jika dibandingkan dengan PDRB tahun pengamatan terakhir (2014).

Sedangkan pada Tahun 2017, diproyeksikan PDRB akan meningkat sebesar Rp.8.975.018.800.000 atau terjadi peningkatan sebanyak $17 \%$ jika dibandingkan dengan PDRB tahun pengamatan terakhir (2014). tahun 2018 diproyeksikan PDRB akan meningkat sebesar Rp.9.410.273.600.000 atau terjadi peningkatan sebanyak $22 \%$ jika dibandingkan dengan PDRB tahun pengamatan terakhir (2014). tahun 2019 diproyeksikan PDRB akan meningkat sebesar Rp.9.845.528.300.000 atau terjadi peningkatan sebanyak $28 \%$ jika dibandingkan dengan PDRB tahun pengamatan terakhir
(2014). Hasil proyeksi ini bisa terjadi dengan asumsi faktor lain konstan (ceteris paribus).

Kemudian untuk persamaan trend tenaga kerja adalah sebagai berikut :

$\mathrm{a}=872.791 / 5=174.558,2$

$\mathrm{b}=26.401 / 10=2.640,1$

Tabel 15 Persamaan Trend Limier

\begin{tabular}{ccccc}
\hline Tahun & $y$ & $x$ & $x^{2}$ & \multicolumn{2}{c}{ xy } \\
\hline 2010 & 176.974 & -2 & 4 & $(353.948)$ \\
2011 & 165.133 & -1 & 1 & $(165.133)$ \\
2012 & 173.235 & 0 & 0 & - \\
2013 & 169.416 & 1 & 1 & 169.416 \\
2014 & 188.033 & 2 & 4 & 376.066 \\
\hline$\Sigma$ & 872.791 & 0 & 10 & 26.401 \\
\hline
\end{tabular}

Sumber: Diolah dariLampiran 4

Berdasarkan nilai a dan $\mathrm{b}$ diatas maka diperoleh persamaan trend sebagai berikut :

$$
Y=174.558,2+2.640,1(X)
$$

Dimana dari persamaan ini menunjukkan bahwa rata rata tenaga kerja selang waktu 5 tahun (2010-2014) adalah sebesar 174.558,2 jiwa dan diproyeksikan setiap tahun berikutnya akan mengalami peningkatan sebesar 2.640,1 jiwa.

\section{Tabel 16 Perkiraan Tenaga Kerja Sektor Pertanian Provinsi Gorontalo} Tahun 2015 - 2019

\begin{tabular}{|c|c|c|c|c|}
\hline \multirow{2}{*}{ Tahun } & \multicolumn{3}{|c|}{ Persamaan Trend } & \multirow{2}{*}{ Perkiraan } \\
\hline & a & b & X & \\
\hline 2015 & $174.558,2$ & $2,640,1$ & 3 & $182,478,5$ \\
\hline 2016 & $174.558,2$ & $2.640,1$ & 4 & $185.118,6$ \\
\hline 2017 & $174.558,2$ & $2,640,1$ & 5 & $187.758,7$ \\
\hline 2018 & $174.558,2$ & $2.640,1$ & 6 & $190.398,8$ \\
\hline 2019 & $174.558,2$ & $2.640,1$ & 7 & $193.038,9$ \\
\hline
\end{tabular}

Sumber: Diolah dariLampiran 4 
Dari Tabel 15 pada tahun 2015 diproyeksikan tenaga kerja akan meningkat sebesar 182.478,5 jiwa kemudian di tahun 2016 meningkat sebesar 185.118,6 jiwa. Dan di tahun 2019 tenaga kerja meningkat sebesar 193.038,9 jiwa.

\section{Pembahasan}

Dari hasil penelitian yang dilakukan melalui analisis location quotient, multiplier, elastisitas dan trend linier dapat kita ketahui seberapa besar peranan sektor pertanian dalam penyerapan tenaga kerja di Provinsi Gorontalo.

Berdasarkan nilai Location Quotient (LQ) PDRB sektor pertanian Provinsi di Gorontalo lebih besar dari 1 atau LQ > 1. Hal ini berarti dari segi pendapatan, sektor pertanian Provinsi Gorontalo merupakan sektor basis yang lebih besar perbandingannya dengan sektor pertanian nasional. Sedangkan untuk Location Quotient (LQ) Tenaga kerja sektor pertanian lebih dari 1 atau LQ $>1$. Hal ini menunjukkan bahwa dari segi penyerapan tenaga kerja sektor pertanian Provinsi Gorontalo merupakan sektor basis yang besar perbandingannya.

Multiplier shortrun (MS) dapat dilakukan dengan terlebih dahulu mengidentifikasi sektor yang tergolong dalam sektor basis. Sektor pertanian Provinsi Gorontalo tergolong dalam sektor basis. Dampak jangka pendek sektor pertanian dari segi pendapatan relatif stabil pada kisaran 2,59-2,70 setiap tahunnya mengalami kenaikan. Ini berarti jika terjadi perubahan Rp.1.000.000 pada sektor pertanian maka akan membawa perubahan sebesar Rp. 2.590.000. Begitu pula dengan multiplier tenaga kerja yang berada pada kisaran 2,45-2,73. Nilai ini dapat di interpretasikan jika kegiatan ekonomi sektor pertanian meningkat Rp. 1.000 maka tenaga kerja yang bekerja pada sektor pertanian akan meningkat sebesar 2.450 jiwa.

Proyeksi PDRB dan tenaga kerja sektor pertanian yang dianalisis menggunakan trend linier menunjukkan bahwa PDRB dan tenaga kerja sektor pertanian tahun 2015 -
2019 mengalami kenaikan Berdasarkan hasil pembahasan diatas maka hipotesis yang diajukan bahwa sektor pertanian mempunyai peran yang besar dalam penyerapan tenaga kerja di Provinsi Gorontalo, terbukti.

\section{KESIMPULAN DAN SARAN}

\section{Kesimpulan}

Peranan sektor pertanian dalam perekonomian di Provinsi Gorontalo sangatlah besar dari tahun ke tahun jika dilihat dari nilai PDRB. Akan tetapi jika dilihat dari segi kontribusinya, sektor pertanian mengalami penurunan setiap tahunnya. Hal ini di karenakan sektor-sektor lain semakin berkembang. Walaupun kontribusi sektor pertanian setiap tahunnya menurun namun sektor pertanian masih merupakan sektor basis.

Peranan sektor pertanian dalam penyerapan tenaga kerja Provinsi Gorontalo tergolong cukup besar dan stabil setiap tahunnya. Dari aspek tenaga kerja sektor pertanian merupakan sektor basis, multiplier tenaga kerja sektor pertanian relatif stabil. Elastisitas tenaga kerja cenderung naik kemudian trend PDRB dan tenaga kerja juga naik.

\section{Saran}

Peranan sektor pertanian Provinsi Gorontalo di lihat dari aspek PDRB dan tenaga kerja sangat besar jika dibandingkan dengan sektor lainnya. Masih besarnya peran sektor pertanian dalam menyerap tenaga kerja yang ada saat ini, menunjukkan bahwa pemerintah perlu menempatkan sektor ini sebagai sektor penting untuk lebih dikembangkan. Kebijakan - kebijakan yang dibuat hendaknya memberikan iklim yang kondusif bagi tumbuh dan berkembangnya sektor pertanian. Perlu adanya perhatian yang lebih dari pemerintah terhadap perkembangan sektor pertanian dan penyerapan tenaga kerja melalui peningkatan kualitas sumber daya manusia (SDM) pada sektor pertanian. 


\section{DAFTAR PUSTAKA}

Agus. 2001. Analisis Struktural Kesempatan Kerja di Indonesia sebelum dan sesudah Krisis Moneter. Makalah Ilmiah Falsafah Sains, Program Pascasarjana Program Doktoral Ilmu Ekonomi. IPB. Bogor.

Amin. A.A, 2015, Peranan Sektor Industri Pengolahan Terhadap Perekonomian dan Penyerapan Tenaga Kerja di Provinsi Sulawesi Utara, Sosek-Unsrat, Manado.http://download.portalgaruda.or g/article.php article $=332024 \&$ val $=1027$ \&title $=$

Badan Pusat Statistik, 2010, Statistik Indonesia, BPS, Jakarta

Jakarta , 2011, Statistik Indonesia, BPS, , 2012, Statistik Indonesia, BPS, Jakarta

2013, Statistik Indonesia, BPS, Jakarta

, 2014, Statistik Indonesia, BPS, Jakarta

Badan Pusat Statistik, 2014. Laporan Perekonomian Provinsi Gorontalo. Gorontalo.

Badan Pusat Statistik, 2015, Produk Domestik Regional Bruto Provinsi Gorontalo Menurut Lapangan Usaha, BPS Gorontalo, Gorontalo.

Badan Perencanaan Pembangunan Daerah Provinsi Gorontalo. 2002. Studi dan Proyeksi Persediaan dan Kebutuhan Tenaga Kerja untuk Program Pembangunan Provinsi Gorontalo Tahun 2004-2013.
Depnakertrans. 2004. Rencana Tenaga Kerja Nasional 2004-2013. http: //www. Nakertrans.go.id.

Kadafi. MF, 2013, Analisis Faktor yang Mempengaruhi Penyerapan Tenaga Kerja Pada Industri Konveksi Kota Malang, Feb-Unibraw, Malang.

Mankiw, N. Gregory. 2003. Macroeconomics. 4th Ed.Worth. New York.

Mulyadi, S. 2003. Ekonomi Sumber Daya Manusia. Dalam Perspektif Pembangunan. Cetakan Kedua. PT Raja Grafindo Persada. Jakarta.

Munif, Abdul. 2009. Strategi dan Pencapaian Swasembada Pangan di Indonesia, Seminar on Agricultural Sciences 2009 tanggal 22 Pebruari 2009 di Tokyo University of Agriculture. Tokyo. diselenggarakan oleh Kedutaan Besar RI Tokyo dan Indonesian Agricultural Sciences Association (IASA).

Priyarsono, D.S. 2005. Revitalisasi Pertanian: Mulai dari Mana?. Indonesia Terkini Series, No. 3-04. Brighten Institute, Bogor.

Sinaga, Azvir. 2005. Analisis Kesempatan Kerja Sehoral di Provinsi Sumatera Utara. Program Pascasarjana Megister Ekonomi Pembangunan. USU. Medan.

Solahuddin. 2009. Pembangunan Pertanian dan Pembangunan Ekonomi. Bogor.

Sukanto. 2011. Peranan Sektor Pertanian Dalam perekonomian Di Jawa Tengah.

Sukirno, S, 2006, Makroekonomi Teori Pengantar, PT. Raja Grafindo Persada, Jakarta

Soekartawi. 2004. Petani Indonesia dalam Menghadapi Persaingan Global. Universitas Brawijaya. Malang. 
Tambunan, Tulus. 2006. Apakah Pertumbuhan di Sektor Pertanian sangat Krusial bagi Pengentasan Kemiskinan di Indonesia ?. Kadin Indonesia-Jetro(2006).http://kadin indonesia.or.id

Tarigan, Robinson,Drs.M.R.P. 2005. Ekonomi Regional Teori dan Aplikasi. PT. Bumi Aksara. Jakarta
Todaro, Michael., P. 2003. Economic Development. Eight Edition. Pearson Education Limited. Eidenburg Gate, Harlow, Essex, England.

Widodo. 2006. Analisis Faktor-faktor yang Mempengaruhi Pertumbuhan Lapangan Kerja Sektoral di Sumatera Utara. Tesis. Program Pascasarjana Magister Ekonomi Pembangunan USU.Medan. 